\title{
THE SMART-CITY: CONCEPT ESSENCE AND ADMINISTRATIVE PROCESSES EVOLUTION
}

\author{
Mykola Pavlov ${ }^{1}$ \\ ${ }^{1}$ Ph.D. student of Information Policy and Digital Technologies Department, National Academy for Public \\ Administration under the President of Ukraine, Kyiv, Ukraine, e-mail: polaxn@gmai.com, ORCID: \\ https://orcid.org/0000-0002-6363-9616
}

\begin{abstract}
The concept of smart city analysis based on the domestic and foreign experience was made. Based on the study of foreign and domestic experience to reveal the essence of the "smart city" concept, to determine the criteria for assigning settlements to the "smart" category and to explore the evolution from traditional to smart administration on local (city) level. The methodology of this study implies the use comparative analysis, the study of domestic and foreign researches, studying digital transformation processes of the public administration system in Ukraine. The approaches to defining "smart city" are revealed. The main contradictions in scientific research on the settlement assignment to the category of "smart" were described. It was argued that despite the large number of publications, scientific sources still do not define a single approach to defining the essence of the "smart city" concept, its components and criteria for classifying a city as smart; usage and adaptation of the term "smart city" in the domestic scientific discourse. The author's vision of the model of administrative processes formation in the settlement on which it can be carried to the category of smart is offered and it was proposed to consider smart-city as special form of administrative processes building, based on a complex multilevel, multi-component, interoperable, automated digital information system that can receive, store, process/analyze, provide, modify and produce new information. The evolution of administrative processes development at the city level from traditional to smart and intelligent is substantiated. It was substantiated that occurrence of smart and intelligent cities is the result of the digital technologies evolution and its usage in administration processes, a key factor is the process automation level.
\end{abstract}

Keywords: smart city, smart administration, public administration, digital technologies

JEL Classification: H70, L86, L88, O38, R50

Formulas: 0; fig.: 4; tabl.:1; bibl.: 10

Introduction. The digital technologies development leads to transformations in the usual processes of ensuring the society's viability. The sphere of public administration is not an exception, as there are digital transformations of administrative processes at all levels (state, regional, local).

In recent years, the concept of building smart cities has become increasingly popular around the world. Scientists have always paid close attention to the study of the category of "smart city", the definition of components and criteria by which certain cities can be classified as "smart". However, today there is no consensus on the definition of a smart city and its components, despite the diversity of research in this area.

Literature review. As already mentioned, research on the issue of "smart city" is quite common. For example, J. Ramon Gil-Garcia, Theresa A. Pardo and Taewoo Nam focus on defining the components of the concept of smart-city and the criteria by which the city can be classified as smart-city [1]. 
Chinese scientist D. Jiang considers approaches to the formation of information systems in the concept of smart city, based on the technologies of "Internet of Things" and "cloud computing" [3].

A group of scientists from Spain, Great Britain, Serbia, Greece and Germany [4] describes the experience of implementing and using Internet of Things technology on the example of the city of Santander (SmartSantander project).

Brazilian scholars are considering approaches to smart governance based on a multi-purpose territorial cadastre and geographic information system, focusing on the analysis of geoinformation, transparency and joint cooperation (participation) of Brazilian capitalists [5].

Another international group of scientists [6] explores the specifics of cooperation between government and the public in terms of smart governance and in the context of smart city formation. In particular, the authors analyze the introduction of various information and communication technologies that simplify the process of government-public interaction.

A group of scientists from the Czech Republic, Hungary and Turkey [7] analyzes the current state and latest trends in the formation of a smart city environment. Researchers believe that smart cities are emerging as a result of highly innovative ICT industries and markets that use the Internet of Things, big data, and cloud technologies to meet the needs of city dwellers.

The researches of Doug Washburn and Usman Sindhu [8] are aimed at explaining the initiative of the smart city to a separate category - IT directors of organizations/institutions. After all, as the authors note, due to the rapid urbanization, managers, businesses and citizens face new challenges.

Despite the large number of publications, scientific sources still do not define a single approach to defining the essence of the "smart city" concept, its components and criteria for classifying a city as smart; usage and adaptation of the term "smart city" in the domestic scientific discourse.

Aims. Based on the study of foreign and domestic experience to reveal the essence of the "smart city" concept, to determine the criteria for assigning settlements to the "smart" category and to explore the evolution from traditional to smart administration on local (city) level.

Methods. The methodology of this study implies the use comparative analysis, the study of domestic and foreign researches, studying digital transformation processes of the public administration system in Ukraine.

Results. The Smart City Index classifies cities based on economic and technological data, as well as their citizens' perceptions of how smart their cities are. The Institute for Management Development, in collaboration with the Singapore University of Technology and Design (SUTD), has released the 2020 Smart City Index with key findings on how technology plays a key role in the COVID-19 era.

In April and May 2020, hundreds of citizens from 109 cities were interviewed about their city's technological support in five key areas: health and safety, mobility, activities, opportunities and governance. According to this assessment, Singapore, Helsinki and Zurich took the top 3 places in the Smart City Index 2020, at the same 
time, many European cities dropped in the rankings. Kyiv took 98th place out of 109 in this ranking, losing 6 positions compared to 2019 [2].

A similar approach is analyzed in the article [10], where the authors offer 10 features to characterize a "smart" city. Among them are: intelligent traffic control systems, smart approach to street lighting, involvement of city residents in administration processest, smart house, introduction of city Wi-Fi network, smart public transport, emergency notifications, emergency buttons, solar panels usage, cashless payments.

In our opinion, the proposed approaches to the smart city definition and named components are undoubtedly important, but it is necessary not only to check the presence of certain features, but also to take into account their interaction with each other.

To illustrate the set of scientific views on the definition of the smart city term, we use the results of a comparative analysis carried out by J. Ramon Gil-Garcia, Theresa A. Pardo and Taewoo Nam [1].

As we can see, common to all these definitions is an attempt to combine technology and administration processes to ensure the population well-being. But the ways of such a combination, the main tools are different and, in our opinion, often are not quite successful.

For example, the level of cooperation between public authorities and citizens is extremely important both before and after the introduction of the smart governance principles, so we do not quite share the opinion expressed by the authors of the publication [6]. The modern ICT introduction into the process of government-public interaction is only a way to improve such interaction, a way of its modernization, but not a criterion of smart administration.

Scientists from the Czech Republic, Hungary and Turkey [7] analyze the current state and latest trends in the formation of a smart city environment and consider smart cities in the context of the creation of "smart floating cities" in the future. Researchers believe that smart cities are emerging as a result of highly innovative ICT industries and markets that use the Internet of Things, big data, and cloud technologies to meet the needs of city dwellers.

However, in our opinion, "Internet of Things, big data, and cloud technologies" are all assistive technologies in the organization of information systems, but in themselves they are not a sign of a smart city. For example, lighting sensors (belong to the IoT) are worthless without sending information to a specific information center, based on the necessary algorithms, and rules, automatic lighting control systems are formed. The fact of big data accumulating does not make sense without a strategic vision for the continued use of this data. Continuing with the example of street lighting sensors, the accumulation of statistical information about lighting on/off provides a basis for forecasting the corresponding costs for the next year and taking into account forecasts in the budgeting process. Given the above, we can conclude that the most effective will be a comprehensive, systematic (rather than situational) use of modern digital technologies in the administration process. 
Before considering the author's view on the smart city concept, we consider it is necessary to dwell on another, broader concept, based on which further we will form the smart city concept - smart administration (Table 1).

\section{Table 1. Scientific views definition of the smart city term}

\begin{tabular}{|c|c|}
\hline Study & Definition \\
\hline Harrison et al. & $\begin{array}{l}\text { "Urban areas that exploit operational data, such as that arising from traffic } \\
\text { congestion, power consumption statistics, and public safety events, to } \\
\text { optimize the operation of city services" }\end{array}$ \\
\hline Toppeta & $\begin{array}{l}\text { [A city] "combining ICT and Web } 2.0 \text { technology with other } \\
\text { organizational, design and planning efforts to dematerialize and speed up } \\
\text { bureaucratic processes and help to identify new, innovative solutions to } \\
\text { city management complexity, in order to improve sustainability and } \\
\text { livability" }\end{array}$ \\
\hline Woods and Goldstein & $\begin{array}{l}\text { "The integration of technology into a strategic approach to sustainability, } \\
\text { citizen well-being, and economic development" }\end{array}$ \\
\hline Kourtit et al. & $\begin{array}{l}\text { "Advanced business and socio-cultural attractiveness, presence of a broad } \\
\text { (public and private) labor force and public facilities, and presence and use } \\
\text { of sophisticated e-services" }\end{array}$ \\
\hline Komninos & $\begin{array}{l}\text { "Territories with high capacity for learning and innovation, which is built- } \\
\text { in the creativity of their population, their institutions of knowledge } \\
\text { creation, and their digital infrastructure for communication and knowledge } \\
\text { management" }\end{array}$ \\
\hline Hall & $\begin{array}{l}\text { "A city that monitors and integrates conditions of all of its critical } \\
\text { infrastructures, including roads, bridges, tunnels, rails, subways, airports, } \\
\text { seaports, communica-tions, water, power, even major buildings, can better } \\
\text { optimize its resources, plan its preventive maintenance activities, and } \\
\text { monitor security aspects while maximizing services to its citizens" }\end{array}$ \\
\hline Kourtit and Nijkamp & $\begin{array}{l}\text { "A promising mix of human capital (e.g. skilled labor force), } \\
\text { infrastructural capital (e.g. high-tech communication facilities), social } \\
\text { capital (e.g. intense and open network linkages) and entrepreneurial capital } \\
\text { (e.g. creative and risk-taking business activities)" } \\
\text { "The result of knowledge-intensive and creative strategies aiming at } \\
\text { enhancing the socio-economic, ecological, logistic and competitive } \\
\text { performance of cities" }\end{array}$ \\
\hline Rios & $\begin{array}{l}\text { "A city that gives inspiration, shares culture, knowledge, and life, a city } \\
\text { that motivates its inhabitants to create and flourish in their own lives" }\end{array}$ \\
\hline Lombardi et al. & $\begin{array}{l}\text { "Smart governance (related to participation); smart human capital (related } \\
\text { to people); smart environment (related to natural resources); smart living } \\
\text { (related to the quality of life); and smart economy (related to } \\
\text { competitiveness)" }\end{array}$ \\
\hline Giffinger et al. & $\begin{array}{l}\text { "A city well performing in a forward-looking way in economy, people, } \\
\text { governance, mobility, environment, and living, built on the smart } \\
\text { combination of endowments and activities of self-decisive, independent } \\
\text { and aware citizens" }\end{array}$ \\
\hline $\begin{array}{l}\text { Natural Res } \\
\text { Defense Co }\end{array}$ & litable, and livable' \\
\hline
\end{tabular}

Source: [1].

In previous studies, we considered smart administration as a form of building administration processes based on the innovative digital smart technologies usage to 
develop behavioral models of administration system based on the accumulated empirical knowledge of administration processes, decisions and results of their implementation; characterized by a clear structure of administrative processes; simplification of the administrative decision-making process in standard conditions; efficiency and speed of internal and external communication processes; high level of transparency of administrative activity and digital security [9].

Given the above, we can conclude that smart-city should be considered as a special form of administrative processes building, based on a complex multilevel, multi-component, interoperable, automated digital information system that can receive, store, process/analyze, provide, modify and produce new information. In fact, such a system consists of many interoperable subsystems (health, education, transport, banking, utilities, etc.) and manages/interacts with them. It should also be noted that the system components are digital (by-default) and digitized processes. In the context of this study, the digitization of the process will mean its transformation into a digital form based on the essence and vision of the end result of this process.

Nowadays the city has multiple areas of administration, such as: education, economy, culture, land resources, administrative services etc. If we consider city administration as a system, the management in each of these areas will act as a separate subsystem. In our opinion, graphically, administration processes can be represented as follows (fig. 1).

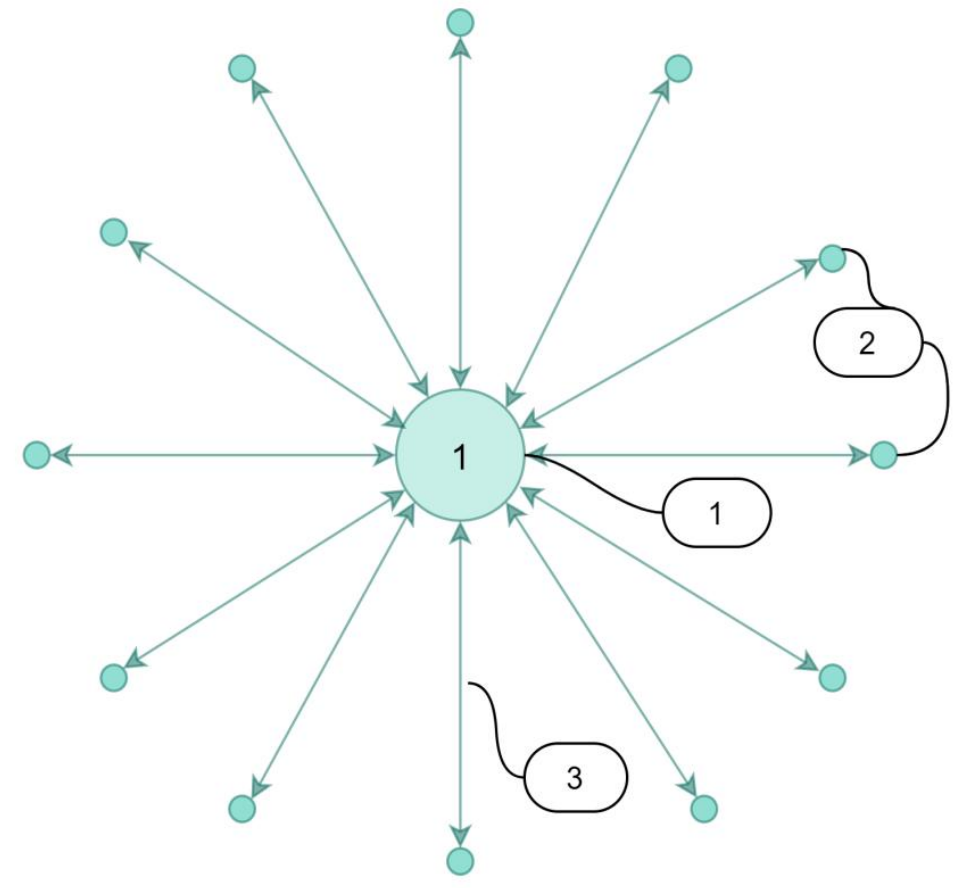

Fig. 1. The model of current city administration processes

Where: 1 - the central information system in the settlement governing body (hereinafter we will use the abbreviation - the control center); 2 - plural management areas in the settlement - subsystems managed by the control center (health, management services, social sphere, transport, security, etc.); 3 - arrows indicate the communication processes between different subsystems. It is worth noting that communications are "thin" and "long in time", so they are not digital-by-default or digitized (automated) in part. Communication between subsystems mostly takes place through the center 
If we digitize the management of one area, based on a new (non-analog) digital system, then this area of activity we can call "smart". The main feature will be that it is based on a smart information system that meets the goals and objectives of the area and its environment. The information system has the ability to meet the maximum area's needs, to provide the most comfortable interaction of stakeholders. Smart systems are often complex and consist of software and certain hardware controlled through software. As an example, to set up a smart traffic control system, you need sensors for cars movement detecting in a certain area, pedestrian flow control sensors, the traffic lights, communication equipment that provides information transmission, as well as software that collects, stores, processes information and development of traffic light algorithms.

A smart system can be considered as formed only if all it's processes are clearly structured in accordance with the goals and objectives, implemented and managed in digital form by the information system taking into account performance indicators (consumption of minimum resources for maximum results). Decision-making is carried out by the responsible person on the basis of the results of the information system function.

Today, the process of "smarting" is heterogeneous - some industries are faster to implement smart technologies, others are slower, in some places they are not implemented at all. Thus, at the present development stage of the smart city administration processes can be depicted as follows (fig. 2).

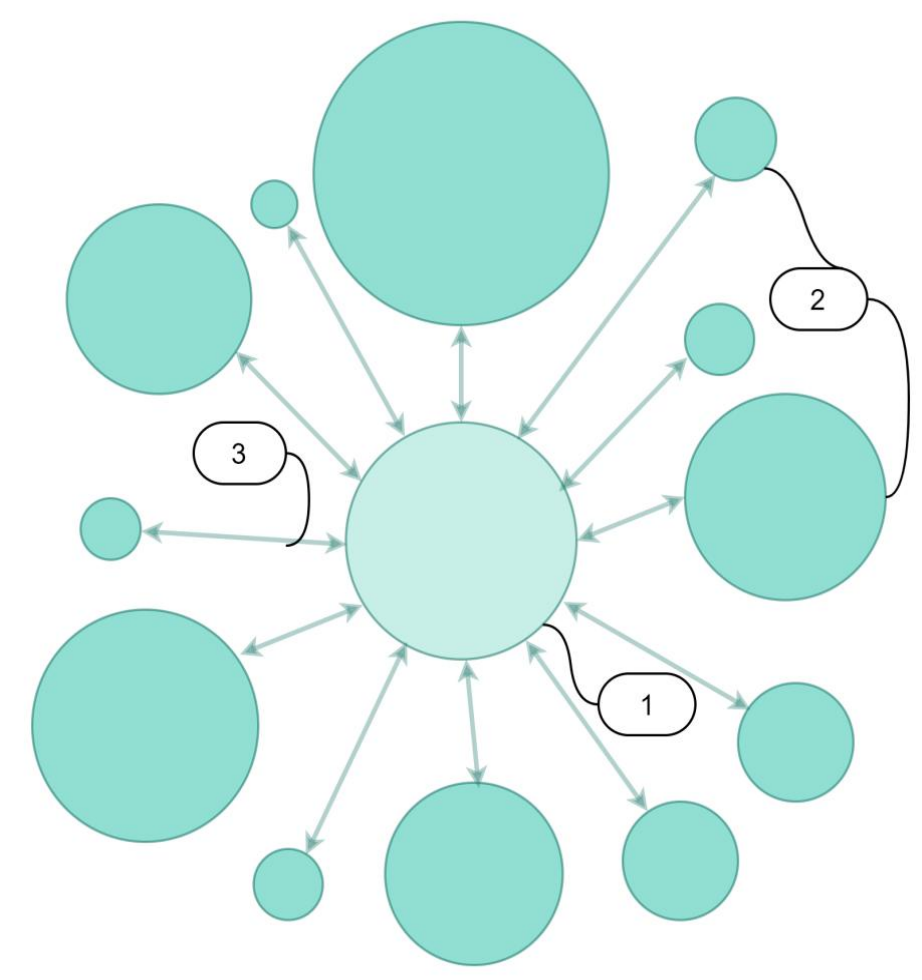

Fig. 2. The model of current city administration processes taking into account smart technologies introduction

Where: 1 - the control center; 2 - subsystems managed by the control center, the circle diameter, marked the subsystems, demonstrates the level of smart technologies implementation; 3 - the communication processes between different subsystems 
Having created a set of local smart subsystems, we get an information system, the center of which provides standardized methods of collecting, storing, converting, creating new and outputting information. At this stage, more reliable communication processes are formed, their digitization/automation takes place. The graphic image of the system will look like this (fig.3).

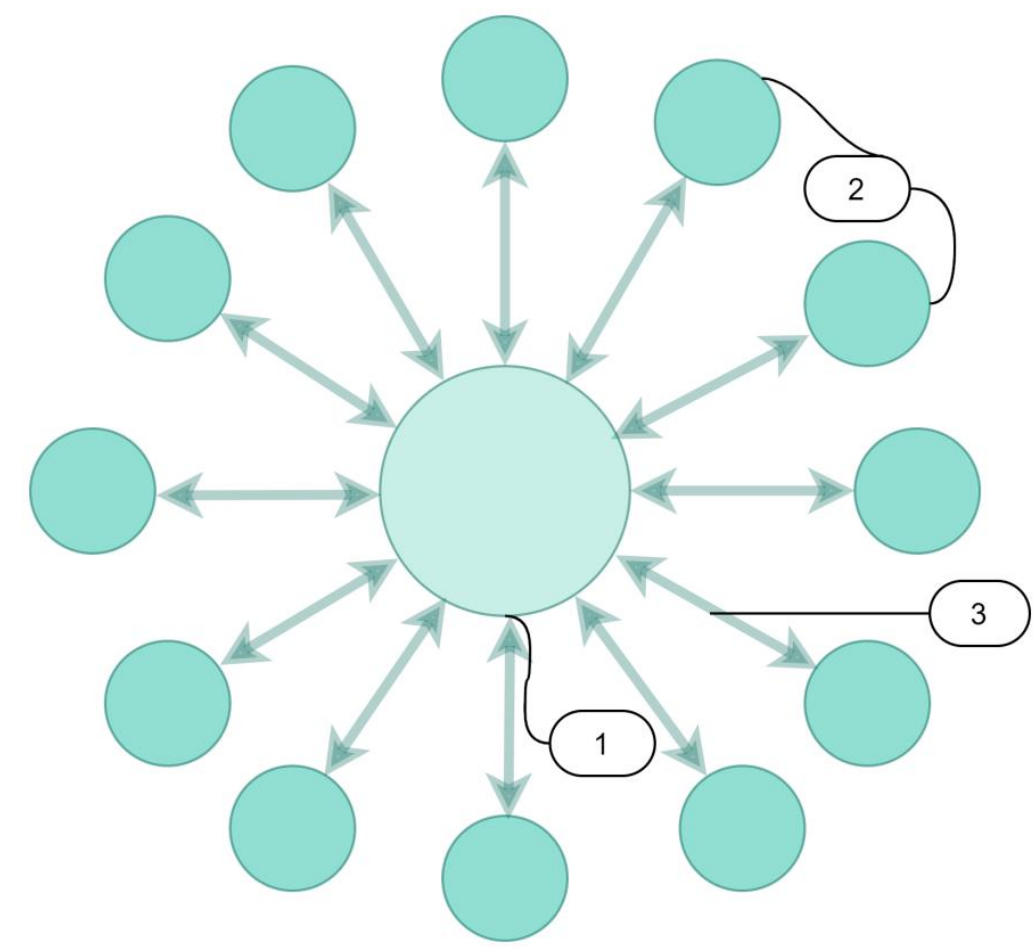

Fig. 3. The model of pre-smart city administration processes

Where: 1 - the control center; 2 - smart-subsystems managed by the control center (health, management services, social sphere, transport, security, etc.); 3 - digital/digitized communication processes between different subsystems

At the same time, we understand that the effective smart subsystems functioning requires the formation of information interaction not only through the center, but also directly between individual subsystems, and therefore they must be interoperable.

Discussion. Thus, the set of local interoperable smart subsystems forms a single information system of the highest level - it is an innovative digital model of the existing analog control system. This is exactly the information system we understand as smart-city. Graphically we can depict it as follows (fig. 4).

Such a digital system ensures the concentration of the necessary information from different areas in a single control center and allows the control center to set tasks that will be automatically responded by local systems. An important component of smart-city is an analytical apparatus that processes and summarizes information both at the individual (local) level and at the highest level. In the future, such hierarchical systems integration can be developed as a smart region and even a smart state. In this case, all systems are interoperable and interaction, if necessary, can take place between any components (between the city and the state, between the village and the region, bypassing the district). 


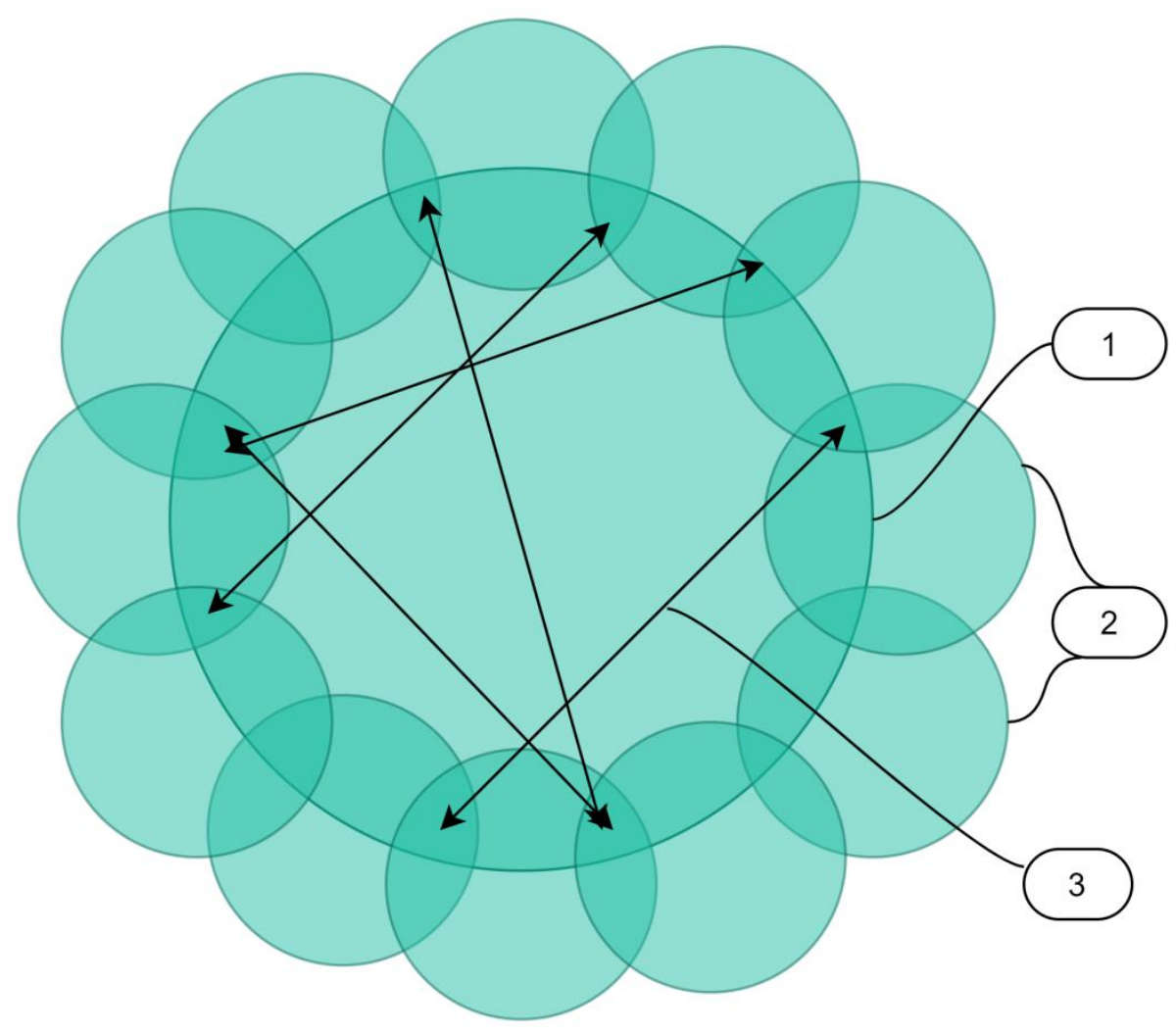

Fig. 4. The model of smart city administration processes

Where: 1 - the control center; 2 - smart-subsystems managed by the control center (health, management services, social sphere, transport, security, etc.); 3 - strong digital communication processes between different subsystems

The next evolutionary development stage of administration processes is the transition to an intelligent administration, characterized by maximum automation of all components of the administration process and the ability to automatically make administrative decisions based on the analysis of previously repeatedly made decisions in similar conditions. The intelligent administration means that all subsystems become part of a unique administration process.

Conclusions. Given the above, we can conclude that occurrence of smart and intelligent cities is the result of the digital technologies evolution and its usage in administration processes, a key factor is the process automation level. With the usual (traditional) forms of city government there is minimal automation, many processes are performed manually or each step requires instructions. The smart cities functioning is characterized by high automation of administration processes. Some decisions in standard conditions are made automatically. The next evolutionary step will be the transition to intellectual administration - a system based on the empirical knowledge, that offers administrative solutions for public servants.

The article provides an author's vision for building administration processes in smart cities and proposes to consider smart-city as special form of administrative processes building, based on a complex multilevel, multi-component, interoperable, automated digital information system that can receive, store, process/analyze, provide, modify and produce new information. In fact, such a system consists of many interoperable subsystems (health, education, transport, banking, utilities, etc.) 
and manages/interacts with them. It should also be noted that the system components are digital (by-default) and digitized processes.

Further scientific research will be aimed at studying the features of administration processes digitalization and the development of practical recommendations for reforming the local government system in the context of smart city concept development.

\section{Author contributions. The authors contributed equally. Disclosure statement. The authors do not have any conflict of interest. References:}

1. Gil-Garcia, J. Ramon \& Pardo, Theresa \& Nam, Taewoo. (2015). What makes a city smart? Identifying core components and proposing an integrative and comprehensive conceptualization. Information Polity. 20. 61-87. 10.3233/IP-150354.

2. Smart City Index 2020. URL: https://www.imd.org/smart-city-observatory/smart-city-index/

3. Jiang, Dingfu. (2019). The construction of smart city information system based on the Internet of Things and cloud computing. Computer Communications. 150. 10.1016/j.comcom.2019.10.035.

4. Sánchez, Luis \& Muñoz, Luis \& Galache, Jose \& Sotres, Pablo \& Santana, Juan \& Gutierrez, Veronica \& Ramdhany, Rajiv \& Gluhak, Alex \& Krco, Srdjan \& Theodoridis, Evangelos \& Pfisterer, Dennis. (2013). SmartSantander: IoT Experimentation over a Smart City Testbed. Computer Networks. 10.1016/j.bjp.2013.12.020.

5. Silva, Andrea Oliveira \& Fernandes, Ricardo. (2020). Smart governance based on multipurpose territorial cadastre and geographic information system: An analysis of geoinformation, transparency and collaborative participation for Brazilian capitals. Land Use Policy. 97. 104752. 10.1016/j.landusepol.2020.104752.

6. Pereira G.V., Cunha M.A., Lampoltshammer T.J., Parycek P. \& Testa M.. (2017) Increasing collaboration and participation in smart city governance: a cross-case analysis of smart city initiatives. Information Technology for Development, VOL. 23, NO. 3, 526-553 https://doi.org/10.1080/02681102.2017.1353946

7. Kirimtat A., Krejcar O., Kertesz A. and Tasgetiren M. F., "Future Trends and Current State of Smart City Concepts: A Survey," in IEEE Access, vol. 8, pp. 86448-86467, 2020, doi: 10.1109/ACCESS.2020.2992441.

8. Washburn, D. and Sindhu, U. (2010) Helping CIOs Understand "Smart City" Initiatives. Forrester Research, February. URL: http://www.uwforum.org/upload/board/forrester_help_cios_smart_city.pdf

9. Namestnik, V. V., Pavlov, M. M. (2020). Elektronne, tsyfrove ta smart-upravlinnia: sutnist ta spivvidnoshennia terminiv [Electronic, digital and smart administration: the terms essence and correlation]. Bulletin of the NAPA. Series «Public Administration». Is. 1 (96). P. 115-121 [in Ukrainian].

10. 10 oznak «rozumnoho mista» [10 signs of a smart city] URL: http://thefuture.news/smart-city/ [in Ukrainian].

Received: April 22, 2021

Approved: May 14, 2021 